\title{
PELAKSANAAN MEDIASI PADA PENYELESAIAN PERCERAIAN DI PENGADILAN AGAMA KUNINGAN
}

\author{
Fitri Purnamasari, Diding Rahmat dan Gios Adhyaksa \\ Fakultas Hukum Universitas Kuningan, Jawa Barat \\ e-mail: fitri.purnamasari@gmail.com
}

\begin{abstract}
The author conducted this research with the background of the implementation of Mediation in Kuningan Religious Court in Kuningan. The purposes of writing this paper are to know how the Implementation on Divorce Settlement in Kuningan Religious Court and to know the factors that affect the success of mediation in the Kuningan Religious Court. The method used in this research is with empirical juridical approach using primary data and secondary data and data collection techniques are interviews, observation and literature study. The results of this research are the mediation arrangements set out in the Supreme Court Regulation (PERMA) Number 1 Year 2016 about Mediation Procedures in Courts and more specifically stipulated in the Decree of the Chief Justice Number 108 / KMA / AK / VI / 2016 on Mediation Governance at the Court. Mediation is the means of dispute resolution through the negotiation process to obtain agreement of the Parties with the assistance of the Mediator. Mediator is a Judge or any other party who has a Mediator Certificate as a neutral party assisting Parties in the negotiation process to see possible dispute resolution without resorting to the disconnection or enforcement of a settlement. Its implementation has been regulated in Law Number 1 Year 1974 about concerning Marriage, Compilation of Islamic Law, and Supreme Court RegulationNumber 1 of 2016 concerning Mediation Procedure in Court. The conclusion of this thesis writing is Mediation which should be one of the alternative process of dispute settlement which can give greater access to justice to the parties in finding satisfactory dispute settlement and to fulfill the sense of justice, and become one of the effective instrument to overcome the problem of case buildup especially for the case Divorce, in the end has not been effectively implemented.
\end{abstract}

Keywords: Mediation, Divorce, Marriage.

\begin{abstract}
Abstrak
Penulis melakukan penelitian ini dengan latar belakang yaitu bagaimana pelaksanaan Mediasi pada Pengadilan Agama Kuningan. Tujuan penulisan ini untuk mengetahui bagaimana Pelaksanaan pada Penyelesaian Perceraian di Pengadilan Agama Kuningan dan untuk mengetahui bagaimana faktorfaktor yang memepengaruhi keberhasilan mediasi di Pengadilan Agama Kuningan. Metode yang digunakan dalam penelitian ini adalah dengan pendekatan yuridis empiris dengan menggunakan data primer dan data sekunder serta alat pengumpulan data yang digunakan melalui wawancara, observasi dan studi pustaka. Hasil penelitian ini adalah pengaturan mediasi diatur dalam Peraturan Mahkamah Agung (PERMA) Nomor 1 Tahun 2016 tentang Prosedur Mediasi di Pengadilan dan lebih spesifik diatur dalam Keputusan Ketua Mahkamah Agung Nomor : 108/KMA/AK/VI/2016 tentang Tata Kelola Mediasi di Pengadilan. Mediasi adalah cara penyelesaian sengketa melalui proses perundingan untuk memperoleh kesepakatan Para Pihak dengan dibantu oleh Mediator. Mediator adalah Hakim atau pihak lain yang memiliki Sertifikat Mediator sebagai pihak netral yang membantu Para Pihak dalam proses perundingan guna mencari berbagai kemungkinan penyelesaian sengketa tanpa menggunakan cara memutus atau memaksakan sebuah penyelesaian. Pelaksanaannya telah di atur dalam Undang-Undang Nomor 1 Tahun 1974 tentang Perkwinan, Kompilasi Hukum Islam, dan Peraturan Mahkamah Agung Nomor 1 Tahun 2016 tentang Prosedur Mediasi di
\end{abstract}


Pengadilan. Kesimpulan dari penulisan skripsi ini adalah Mediasi yang seharusnya menjadi salah satu alternatif proses penyelesaian sengketa yang dapat memberikan akses keadilan yang lebbesar kepada para pihak dalam menemukan penyelesaian sengketa yang memuaskan dan mmemenuhi rasa keadilan, serta menjadi salah satu instrumen efektif mengatasi masalah penumpukan perkara khususnya untuk perkara perceraian, pada akhirnya belum efektif dilaksanakan.

Kata Kunci : Mediasi, Perceraian, Perdata

\section{PENDAHULUAN}

Negara Indonesia adalah Negara Hukum, Berdasarkan Pasal 1 ayat ( 3 ) Undang Undang Dasar Negara Republik Indonesia Tahun 1945, Selain itu Indonesia amat sangat menjungjung tinggi agama berdasarkan asas ketuhan yang maha esa berdasarkan Pasal 29 ayat ( 1 ) Undang - Undang Dasar Tahun 1945. Yang mana dalam Pasal 28 B ayat ( 1 ) Undang Undang Dasar 1945 menyatakan bahwa " setiap orang berhak membentuk keluarga dan melanjutkan keturunan melalui perkawinan yang sah ". Allah telah menciptakan lelaki dan perempuan sehingga mereka dapat berhubungan satu sama lain, sehingga mencintai, menghasilkan keturun serta hidup dalam kedamaian sesuai dengan perintah Allah SWT dan petunjuk dari Rasul-Nya. ${ }^{1}$

Dalam negara hukum yang tunduk pada the rule of law, kedudukan peradilan dianggap sebagai pelaksanaan kekuasaan kehakiman yang berperan sebagai katup penekan atas segala pelanggaran hukum dan ketertiban masyarakat. Peradilan dapat dimaknai juga dengan tempat terakhir mencari kebenaran dan keadilan, sehingga secara teoritis masih diandalkan sebagai badan yang berfungsi dan berperan menegakkan kebenaran dan keadilan. ${ }^{2}$

Kesadaran hukum, ketaatan hukum, dan ekfetivitas perundang - undangan adalah tiga unsur yang saling berhubungan. Sering orang mencampuradukan antara kesadaran hukum dan ketaatan hukum, padahal meskipun sangat erat hubungannya, namun tidak pernah sama. Kedua unsur itu memang sangat menentukan efektif

\footnotetext{
${ }^{1}$ Abdul Rhman I, Perkawinan dalam Syariat Islam, Rineka Cipta, Jakarta, hlm.1.

2 M. Yahya Harahap, Hukum Acara Perdata: tentang Gugatan, Persidangan, Penyitaan, Pembuktian dan Pututsan Pengadilan, Sinar Grafika, Jakarta, 2008, hlm.229.
}

atau tidaknya pelaksanaan perundang undangan di dalam masyarakat. ${ }^{3}$

Kepemimpinan yang kuat dan manajemen yang efektif diaktualisasikan dalam bentuk kebijakan - kebijakan yang mengarah kepada evaluasi dan berusaha mengantisipasi perubahan yang terjadi serta mengakomodasi kebutuhan dan harapan masyarakat akan pelayanan yang berkeadilan. Proses penanganan perkara yang efektif dan efisien akan terwujud jika ada sinergi yang baik antara hakim dan staff pengadilan. Hakim memfokuskan diri pada proses pemeriksaan perkara sementara staff menangani aspek administrasinya. Ketetapan waktu dan durasi penangan perkara harus bener - benar dimonitor. Perkara - perkara diperiksa dan diputus mengikuti Standard Operating Procedures (SOP) yang telah ditetapkan.

Untuk mengatasi problematika sistem peradilan yang tidak efektif dan efisien, maka muncul alternatif penyelesaian sengketa dengan perdamaian. Dalam hukum acara di Indonesia pada Pasal 130 Herziene Inlandsch Reglement ( Selanjutnya disebut HIR ) Maupun Pasal 154 Rechtstreglement Voor De Buitengewesten ( Selanjutnya disebut R.Bg ) kedua Pasal dimaksud mengenal dan menghendaki penyelesaian sengketa secara damai. ${ }^{4}$

Upaya perdamaian yang dimaksud pada Pasal 130 ayat ( 1 ) HIR bersifat Imperatif ${ }^{5}$ ( Selanjutnya disebut Perintah ). Artinya hakim berkewajiban mendamaikan pihak - pihak yang berperkara di Pengadilan sebelum dimulainya persidangan. Sang Hakim berusaha mendamaikan denga cara - cara yang baik agar ada titik temu sehingga tidak perlu ada proses

\footnotetext{
${ }^{3}$ Achmad Ali \& Wiwie Heryani, Menjelajahi Kajian Empiris Terhadap Hukum, Kencana, Jakarta, 2012, hlm.140.

${ }^{4}$ R. Tresna, Komentar HIR, Paradaya Paramita, Jakarta, 2005, hlm.110.

${ }^{5}$ M. Yahya Harahap, Op.Cit, hlm.231.
} 
persidangan yang lama dan melelahkan. Walau demikian, upaya damai yang dilakukan tetap mengedepankan kepentingan semua pihak yang bersengketa sehingga semua merasa puas dan tidak ada yang merasa dirugikan.

Mahkamah Agung sebagai salah satu penyelenggara Kekuasaan Kehakiman mempunyai tugas pokok untuk menerima, memeriksa dan mengadili serta menyelesaikan setiap perkara yang diajukan kepadanya. Dalam menyelesaikan setiap perkara, aparat peradilan ( hakim ) harus berpegang pada asas - asas peradilan yang antara lain cepat, sederhana dan biaya ringan.

Lahirnya mediasi pada pengadilan melalui Peraturan Mahkamah Agung ( PERMA) Nomor 1 Tahun 2016, merupakan penegasan ulang terhadap PERMA sebelumnya yaitu PERMA Nomor 1 Tahun 2008. Dilatar belakangi dengan penumpukan perkara di lingkungan peradilan terutama dalam perkara kasasi, mediasi diharapkan menjadi instrumen efektif dalam proses penyelesian sengketa yang lebih cepat dan murah, serta dapat memberikan akses yang lebih besar kepada para pihak menemukan penyelesaian yang memuaskan dan memenuhi rasa keadilan.

Pasal 130 HIR/154 R.Bg yang memerintahkan usaha perdamaian oleh hakim, dijadikan sebagai modal utama dalam membangun perangkat hukum mediasi pengadilan, yang sudah dirintis sejak Tahun 2002 melalui Surat Edaran Mahkamah Agung ( SEMA ) Nomor 1 Tahun 2002 tentang Pemberdayaan Pengadilan Tingkat Pertama Menerapkan Lembaga Damai Pasal 130 HIR/R.Bg yang kemudian pada tahun 2003 disempurnakan melalui SEMA Nomor 2 Tahun 2003 tentang Prosedur Mediasi di Pengadilan.

Kehadiran PERMA Nomor 1 Tahun 2016 dimaksudkan untuk memberikan kepastian, ketertiban, kelancaran dalam proses mendamaikan para pihak untuk menyelesaikan suatu sengketa perdata. Hal ini dapat dilakukan dengan mengintensifkan dan mengintegrasikan proses mediasi kedalam prosedur berperkara di Pengadilan. Mediasi dapat kedudukan penting dalam PERMA Nomor 1 Tahun 2016, karena proses mediasi merupakan bagian yang terpisahkan dalam proses berperkara di pengadilan.

Belum terjadi perubahan yang signifikan terhadap jumlah perkara yang masuk ke dalam proses persidangan, sehingga perceraian belum sesuai dengan harapan. Berdasarkan hal tersebut maka dianggap perlu untuk dijadikan harapan.

\section{RUMUSAN MASALAH}

Adapun yang menjadi pokok permasalahan yang akan menjadi fokus perhatian utama yang akan dibahas dalam penulisan ini yaitu Bagaimana Pengaturan Pelaksanaan Mediasi pada Penyelesaian Perceraian di Pengadilan Agama Kuningan? Bagaimana faktor-faktor yang mempengaruhi keberhasilan Mediasi pada Penyelesian Perceraian di Pengadilan Agama Kuningan?

\section{METODE PENELITIAN}

Sesuai dengan permasalahan yang di ajukan di atas, maka penulis menggunakan metode penelitian deskriptif kualitatif, penelitian deskriptif adalah penelitian yang dimaksud untuk memberikan data seteliti mungkin tentang manusia, keadaan dan gejala gajala lainnya sedangkan penelitian kualitatif penelitian yang dilakukan dengan pengumpulan data berupa kata - kata, gambar - gambar serta informasi verbal atau naratik dan bukan dalam bentuk angka. ${ }^{6}$

Metode pendekatan yang dipergunakan yaitu yuridis empiris, artinya hukum sebagai gejala masyarakat, sebagai institusi sosial atau perilaku yang mempola dan pendekatan dari sudut kaidah-kaidah pelaksanaan peraturan yang berlaku dalam masyarakat. Sumber data terdiri dari data primer yaitu observasi, wawancara dan data skunder yaitu bahan hokum primer terdiri dari : Undang Undang Dasar Negara Republik Indonesia 1945, UndangUndang Nomor 1 Tahun 1974 tentang Perkawinan, Peraturan Mahkamah Agung (PERMA) Nomor 1 Tahun 2016 tentang Prosedur

${ }^{6}$ Rony Hanitijo soemitro, Metodelogi Penelitian Hukum dan Judimentri Ghalia Indonesia, Jakarta, 2000, hlm. 19. 
Mediasi di Pengadilan, Keputusan Ketua Mahkamah Nomor :108/KMA/SK/VI/2016, Kompilasi Hukum Islam (KHI).

\section{PEMBAHASAN}

Pengaturan Mediasi Pelaksanaan Mediasi Pada Penyelesaian Perceraian di Pengadilan Agama Kuningan

Kata "mediasi" berasal dari bahasa inggris, "mediation" yang artinya pelaksanaan sengketa yang melibatkan pihak ketiga sebagai penegah atau penyeleseaian sengketa secara menengahi, yang menengahinya dinamakan mediator atau orang yang menjadi penegah. ${ }^{7}$

Secara umum, dalam Kamus Besar Bahasa Indonesia, disebutkan bahwa yang dimaksud dengan mediasi adalah proses pengikutsertaan pihak ketiga dalam menyelesaikan suatu perselisihan sebagai penasehat. ${ }^{8}$ Sedangkan pengertian perdamaian menurut hukum positif sebagaimana dicantumkan dalam Pasal 1851 KUHP (Kitab Undang - Undang Hukum Perdata) adalah suatu perjanjian dimana kedua belah pihak dengan menyerahkan, menjanjikam atau menahan suatu barang, mengakhiri suatu perkara yang sedang bergantung atau mencegah timbulnya suatu perkara kemudian. ${ }^{9}$

Mediasi dalam literatur Hukum Islam bisa disamakan dengan konsep Tahkim yang secara etimologis berarti menjadikan seseorang sebagai pihak ketiga atau yang disebut Hakam sebagai Penegah suatu sengketa. ${ }^{10}$

Dasar hukum perdamaian atau mediasi dalam Hukum Islam adalah sebagaimana firman Allah: Artinya: "Sesungguhnya orang - orang mukmin itu bersaudara, karena itu damaikanlah antara

\footnotetext{
7 Joni Emirzon, Alternatif Penyelesaian Sengketa di Luar Pengadilan (Negoisasi, Mediasi, Konsiliasi, Arbitrase), Gramedai Pustaka Utama, Jakarta, 2001, hlm. 69

8 Tim Penyusun Kamus Pusat Pembinaan dan Pengembangan Bahasa, Kamus Besar Bahasa Indonesia, Balai Pustaka, Jakarta, 2000, hlm. 640

9 Subekti \& Tjitrosudibio, Kitab Undang-undang Hukum Perdata, Pradnya Paramita, Jakarta, 1985, hlm 414

10 Rosyadi Rahmat dan Ngatino, Arbitrase dalam Hukum Islam dan Hukum Positif, PT. Citra Adiya Bakti, Bandung, hlm. 43
}

kedua saudaramu (yang berselisih) dan bertakwalah kepada Allah agar kamu mendapat rahmat".

Dasar hukum mediasi di Indonesia adalah :

1. Pancasila dan UUD 1945, disiratkan dalam filosofinya bahwa asas penyelesaian sengketa adalah musyawarah untuk mufakat:

2. HIR Pasal 130 ( HIR= Pasal $154 \mathrm{RBg}=$ Pasal 31 Rv );

3. UU Nomor. 1 Tahun 1974 jo Pasal 39 , UU Nomor.7 Tahun 1989 jo. UU nomor 3 Tahun 2006 jo. UU nomor 50 Tahun 2009 tentang Peradilan Agama Pasal 65 dan 82, PP Nomor. 9 Tahun 1975 Pasal 31 dan KHI Pasal 115, 131 ayat ( 2 ), 143 ayat ( 1 ) dan ( 2 ), dan 144.29;

4. Surat Edaran Mahkamah Agung (SEMA ) Nomor.1 Tahun 2002 tentang Pemberdayaan Pengadilan Tingkat Pertama Menerapkan Lembaga Damai ( Eks Pasal 130 HIR/154 RBg);

5. Peraturan Mahkamah Agung (PERMA) Nomor. 01 tahun 2016 tentang Prosedur Mediasi di Pengadilan;

6. Mediasi atau APS di luar Pengadilan diatur dalam Pasal 6 UU Nomor. 30 Tahun 1999 tentang Arbitrase dan Alternatif Penyelesaian Sengketa;

Dalam pasal - pasal tersebut, disebutkan bahwa hakim wajib mendamaikan para pihak yang berperkara sebelum putusan diajukan. Usaha mendamaikan ini dapat dilaksanakan pada setiap sidang pemeriksaan. Khusus perkara perceraian, dalam upaya mendamaikan itu pula hakim wajib menghadirkan pihak keluarga atau orang - orang terdekat dari pihak - pihak yang berperkara untuk didengar keterangannya dan meminta bantuan mereka agar kedua pihak berperkara itu dapat rukun dan damai kembali. Apabila upaya untuk mendamaikan ini tidak berhasil, maka barulah hakim menjatuhkan putusan cerai, terhadap putusan ini dapat dimintakan upaya banding dan atau kasasi. 


\section{Faktor-Faktor yang Mempengaruhi Keberhasilan Mediasi di Pengadilan Agama Kuningan

Mediasi dalam literatur Hukum Islam
dapat ditemui dalam firman Allah

"Artinya : urusan mereka ( diputuskan ) dengan musyawarah antara mereka".

Pada ayat Al - Qur'an diatas, Allah menganjurkan kepada manusia agar dapat menyelesaikan sengketa melalui musyawarah. Hal ini sejalan dengan sifat mediasi yang penyelesaian sengketanya bersifat consensus (kesepakatan) dengan cara negosiasi. Agar dapat diselesaikan tanpa melalui proses litigasi.

Di Indonesia, bila dilihat secara mendalam, tata cara penyelesaian sengketa secara damai telah lama dan biasa dipakai oleh masyarakat Indonesia. Hal ini dapat dilihat dari hukum adat yang menempatkan kepala adat sebagai penengah dan memberi putusan adat bagi sengketa diantara warganya.Terlebih pada tahun 1945, tata cara ini secara resmi menjadi salah satu falsafah negara dari bangsa Indonesia yang tercermin dalam asas musyawarah untuk mufakat.

Mediasi atau alternatif penyelesaian sengketa di Indonesia adalah merupakan culture ( budaya ) bangsa Indonesia sendiri. Baik dalam masyarakat tradisional maupun sebagai dasar negara pancasila yang dikenal istilah musyawarah untuk mufakat. Seluruh suku bangsa di Indonesia pasti mengenal makna dari istilah tersebut, walaupun penyebutannya berbeda, akan tetapi mempunyai makna yang sama. dalam klausula - klausula suatu kontrak atau perjanjian, pada bagian penyelesaian sengketa selalu diikuti dengan kata - kata "kalau terjadi sengketa atau perselisihan akan diselesaikan dengan cara musyawarah dan apabila tidak tercapai suatu kesepakatan akan diselesaikan di Pengadilan Negeri". ${ }^{11}$

\section{Prinsip - Prinsip Mediasi Dalam AL - Quran}

${ }^{11}$ Mahkamah Agung RI, Mediasi dan Perdamaian, mimeo, tt: tp, 2004, hlm. 15
Mohammed Abu Nimer merumuskan 12 prinsip penyelesian sengketa ( konflik) yang dibangun Al - Quran dan di praktikkan Nabi Muhammad. Prinsip - prinsip tersebut adalah :

a. Terwujudnya keadilan

b. Pemberdayaan Sosial

c. Universalitas dan Martabat Kemanusiaan

d. Prinsip Kesamaan (Equality)

e. Melindungi Kehidupan Manusia

f. Perwujudan Damai

g. Pengetahuan dan Kekuatan Logika

h. Kreatif dan Inovatif

i. Saling memaafkan

j. Tindakan Nyata

k. Pelibatan Melalui Tanggung Jawab Individu

I. Sikap Sabar

2. Asas - Asas Umum dalam Proses Mediasi

Peraturan Mahkamah Agung menyebutkan bahwa mediasi merupakan proses yang berada di luar litigasi, maka menurut D.Y. Witanto, proses mediasi memiliki ciri dan prinsip yang berbeda dengan prinsip persidangan pada umunya yang mana perbedaan tersebut antara lain:

a. Proses mediasi bersifat informal. Mediator sebagai fasiliator akan menggunakan pendekatan non legal dalam menyelesaikan perkara, sehingga tidak kaku dan rigid;

b. Waktu yang dibutuhkan relatif singkat. Dalam Pasal 24 ayat (2) Peraturan Mahkamah Agung ( selanjutnya disebut PERMA ) Nomor 1 Tahun 2016 disebutkan bahwa proses mediasi berlangsung paling lama 30 ( tiga puluh ) hari terhitung sejak penetapan perintah melakukan Mediasi dan dapat di perpanjang paling lama 30 (tiga puluh) hari terhitung sejak berakhir jangka waktu sebagaimana dimaksud pada ayat (2), Pasal 13 ayat (3);

c. Penyelesaian didasarkan atas kesepakatan para pihak. Mediator hanya sebagai fasiliator agar tercapai sebuah 
kesepakatan yang dapat menguntungkan kedua belah pihak;

d. Biaya ringan dan murah. Bila para pihak menggunakan jasa mediator non hakim, biaya mediasi tergantung kebutuhan selama berlangsungnya proses mediasi. Namun bila menggunakan jasa mediator hakim, biaya akan jauh lebih murah, yakni hanya dikenakan biaya pemanggilan bila ada pihak yang tidak hadir sesuai perjanjian. Sedangkan untuk jasa mediator dari kalangan hakim dan penggunaan ruang mediasi di pengadilan tidak dipungut biaya apapun;

e. Prosesnya bersifat tertutup, dalam Pasal 5 ayat ( 1 ) Peraturan Mahkamah Agung ( selanjutnya disebut PERMA ) Nomor 1 Tahun 2016 disebutkan bahwa proses mediasi pada dasarnya bersifat tertutup kecuali Para Pihak menghendaki lain;

f. Kesepakatan damai bersifat mengakhiri perkara, artinya bila para pihak bersepakat untuk berdamai, gugatan perkara harus dicabut, sehingga perkara dinyatakan selesai;

9. Proses mediasi dapat mengesampingkan pembuktian, para pihak tidak perlu saling berdebat dengan alasan bukti - bukti, namun yang diupayakan adalah mempertemukan titik temu dari permasalahan;

h. Proses mediasi menggunakan pendekatan komunikasi audio visual jarak jauh yang memungkinkan semua pihak saling melihat dan mendengarkan secara langsung serta berpartisipasi dalam pertemuan dalam Pasal 5 ayat ( 3 ).

i. Hasil mediasi bersifat win-win solutisn, tidak ada istilah menang kalah. Semua pihak harus menerima kesepakatan yang mereka buat bersama-sama;

\section{Para Pihak dalam Proses Mediasi}

Para pihak yang terlibat dalam proses mediasi adalah para pihak yang terlibat dalam suatu sengketa bersama dengan pihak ketiga yang netral (mediator).

\section{a. Mediasi dalam Perkara Perceraian}

\begin{abstract}
Perkara perceraian termasuk perkara contentius ${ }^{12}$ (suatu perkara yang didalamnya berhadapan kedua belah pihak yang bersengketa. disebut juga dengan perkara gugatan) dan termasuk karakteristik sengketa emosional.
\end{abstract}

Seperti telah diketahui, bahwa ada 3 karakteristik sengketa, yaitu: ${ }^{13}$

1. Formal, adalah sengketa tentang suatu norma hukum atau status hukum suatu obyek tertentu yang menjadi sengketa, dalam hal ini sasaran akhirnya adalah kepastian hukum:

2.Material/kebendaan, damai berarti tercapainya persamaan persepsi ( kesepakatan) tentang pembagian hak atas benda, penaksiran nilai atau harga, pemenuhan kewajiban antar pihak, atau pemecahannya lebih lanjut. Hal ini dapat terjadi dalam sengketa harta waris, hibah, wasiat, shodaqoh, harta bersama dalam perkawinan. Dalam hal ini, sasarannya ialah rasa keadilan;

3. Emosional, maka damai berarti tercapainya kesepakatan untuk saling memaafkan, saling menghormati, atau menghargai dan saling membantu sehingga tercipta kembali hubungan kehidupan yang damai, rukun, tertib dan tentram, karena mereka akan hidup rukun kembali dalam rumah tangga. Dalam hal ini yaitu perkara perceraian;

\section{b. Manfaat Mediasi}

Sebagaimana umumnya lembaga alternatif penyelesaian sengketa yang lain, maka keunggulan dan manfaat mediasi masih terkait dengan karakteristik umum keunggulan dan manfaat yang terdapat pada alternatif penyelesaian sengketa antara lain, yaitu:

1. Relatif lebih murah dibandingkan dengan alternatif-alternatif yang lain;

${ }^{12}$ Mukti Arto, Praktek Perkara Perdata pada Pengadilan Agama, Pustaka Pelajar, Yogyakarta, 2008, hlm. 41

${ }^{13}$ M. Yahya Harahap,Op. Cit, hlm. 192 
2. Adanya kecenderungan dari pihak yang bersengketa untuk menerima dan adanya rasa memiliki putusan mediasi;

3. Dapat menjadi dasar bagi pihak yang bersengketa untuk menegosiasikan sendiri sengketa-sengketa yang mungkin timbul dikemudian hari;

4. Terbukanya kesempatan untuk menelaah masalah-masalah yang merupakan dasar dari suatu sengketa;

5. Membuka kemungkinan adanya saling percayaan diantara pihak yang bersengketa sehingga dapat dihindari rasa permusuhan dan dendam: ${ }^{14}$

6. Dalam pelaksanaan mediasi segala hal yang diungkap serta sifat acara mediasi adalah rahasia. Berbeda dengan cara litigasi yang sifatnya terbuka untuk umum, sifat tidak terbuka untuk umum ini bisa membuat pihak-pihak yang bersengketa merasa nyaman selama pelaksanaan mediasi dalam rangka penyelesaian sengketa. Karena tanpa adanya kekhawatiran sengketa yang terjadi diantara mereka menjadi perhatian publik;

7. Penyelesaian melalui mediasi mempersingkat waktu penyelesaian berperkara, memperingan beban ekonomi keuangan, dan yang tidak kalah penting adalah mengurangi beban psikologis yang akan mempengaruhi berbagai sikap dan kegiatan pihak yang berperkara;

8. Salah satu manfaat mediasi apabila dilihat dari kekuatan putusan yang dihasilkan adalah karena pada hakekatnya mekanisme mediasi adalah upaya untuk mengarahkan para pihak yang bersengketa agar menyelesaikan sengketa yang terjadi dengan perdamaian maka kekuatan hukum mediasi tidak jauh berbeda dengan kekuatan akta perdamian. Putusan

${ }^{14}$ Munir Fuady, Arbitrase Nasional: Alternative Penyelesaian Sengketa Bisnis, PT. Citra Aditya Bakti, Bandung, 2005, hlm. 50 perdamaian hasil mediasi mempunyai kekuatan eksekutorial sebagaimana putusan yang dihasilkan dari persidangan ( proses litigasi );

9. Apabila sudah tercapai kesepakatan para pihak, maka hakim tinggal membuatkan yang dalam amar putusan menjatuhkan putusan sesuai dengan isi persetujuan dictum (amar) : menghukum para pihak untuk menaati dan melaksanakan isi persetujuan perdamaian" amar putusannya selanjutnya adalah "menghukum para pihak membayar biaya perkara dengan ditanggung masing-masing pihak secara sama besar";

10. Bagi Mahkamah Agung, apabila mediasi di pengadilan bisa terlaksana dengan baik, maka hal itu akan mengurangi tumpukan perkara yang harus diselesaikan oleh Mahkamah Agung;

11. Pemberdayaan individu. Orang yang menegosiasikan sendiri masalahnya sering kali merasa mempunyai lebih banyak kuasa daripada mereka yang melakukan advokasi melalui wakil seperti pengacara: ${ }^{15}$

c. Bentuk - bentuk Penyelesaian Sengketa

Secara garis besar bentuk penyelesian sengketa di bagi menjadi dua bagian yaitu:

1. Bentuk penyelesian secara litigasi (peradilan);

2. Bentuk penyelesaian sengketa secara non litigasi;

Keberhasilan atau kegagalan mediasi sangat dipengaruhi faktor - faktor pendukung dan penghambat selama proses mediasi. Berikut faktor - faktor pendukung keberhasilan mediasi:

1. Kemampuan mediator, kegigihan mediator untuk merealisasikan keberhasilan mediasi dan kemampuan atau skill dan penguasaan mediator

${ }^{15}$ Rahmadi Usman, Pilihan Penyelesaian Sengketa di Luar Pengadilan, PT Aditya Bakti, Bandung, 2003, hlm. 83-85 
terhadap teknik mediasi;

2. Faktor sosiologis dan psikologis, yang bergantung pada rasa ketidaknyamanan;

3. Moral dan kerohanian;

4. Iktikad baik para pihak, iktikad baik untuk mengakhiri sengketa melalui mediasi dan para pihak memiliki kesadaran untuk berdamai dan menyadari kekeliruannya;

Faktor penghambat keberhasilan mediasi, sebagai berikut:

1. Keinginan kuat untuk bercerai;

2. Sudah terjadi konflik yang berkepanjangan;

3. Faktor psikologi atau kejiwaan;

\section{SIMPULAN}

Berdasarkan diuraikan diatas maka penulis dapat mentarik kesimpulan sebagai berikut Pelaksanaan Mediasi pada Penyelesaian Perceraian di Pengadilan Agama Kuningan telah di atur dalam : pelaksannan Mediasi di Pengadilan diwajibkan bagi setiap perkara yang diajukan ke Pengadilan tingkat pertama kecuali sengketa yang termasuk dalam Pasal 4 ayat (2) Peraturan Mahkamah Agung Nomor 1 Tahun 2016, Prosedur mediasi dibagi menjadi : PraMediasi yaitu tahapan sebelum dilkasanakannya proses mediasi, antara lain penjelasan Kewajiban para pihak untuk hadir dan beritikad baik pada Mediasi, pemilihan Mediator serta batas waktunya, dan pemanggilan para pihak; dan Proses Mediasi yaitu tahapan dimana Mediator memulai melakukan proses mediasi dengan ruang lingkup yang tidak terbatas hanya pada posita dan petitum gugatan, Proses Mediasi ini antara lain Pertemuan Mediator dengan kedua belah pihak, Pertemuan Mediator dengan salah satu pihak ( kaukus), Penyerahan Resume Perkara, Keterlibatan Ahli dan Tokoh Mayarakat hingga kesepakatan - kesepakatan Mediasi dan Faktor - Faktor yang Mempengaruhi Keberhasilan Mediasi di Pengadilan Agama Kuningan adalah sebagai berikut : Kemampuan Mediator, Faktor Sosiologis dan Psikologis para pihak, Prilaku para pihak, dan Itikad Baik para pihak. Faktor penghambat dalam proses mediasi yang diupayakan oleh Hakim Pengadilan Agama Kuningan dalam mengatasi hambatan - hambatan dalam proses mediasi belum mampu untuk menciptakan mediasi yang efektif, hal ini dikarenakan faktor para pihak sendiri yang memang tidak mau adanya perdamaian.

\section{SARAN}

Berdasarkan hal - hal yang telah diuraikan diatas maka penulis dapat memberikan saran-saran yaitu Hakim pengadilan yang bertindak selaku mediator dapat melakukan upaya mediasi dengan semaksimal mungkin, agar masyarakat khususnya yang berperkara di Pengadilan Agama Kuningan dapat mendapat keadilan dan merasakan manfaat bersama (win win solution) dan Untuk lebih mengefektifkan proses mediasi di Pengadilan Agama Kuningan, diharapkan sistem ini lebih dioptimalkan pelaksanaannya dan dilakukan secara terencana dan sistematis sehingga para pihak yang bersengketa lebih yakin dan lebih percaya, berdamai lebih baik dari pada melanjutkan proses hukum persidangan, yang cukup memakan waktu dan biaya. Dalam hal ini diharapkan di dalam melaksanakan proses mediasi, selain sistematis, rasional, juga menggunakan metodologi serta pendekatan hukum yang efektif.

\section{DAFTAR PUSTAKA}

Abdul Rhman I, Perkawinan dalam Syariat Islam, Rineka Cipta, Jakarta.

Achmad Ali \& Wiwie Heryani, Menjelajahi Kajian Empiris Terhadap Hukum, Kencana, Jakarta, 2012.

Joni Emirzon, Alternatif Penyelesaian Sengketa di Luar Pengadilan (Negoisasi, Mediasi, Konsiliasi, Arbitrase), Gramedai Pustaka Utama, Jakarta, 2001.

Mahkamah Agung RI, Mediasi dan Perdamaian, mimeo, tt: tp, 2004.

Mukti Arto, Praktek Perkara Perdata pada Pengadilan Agama, Pustaka Pelajar, Yogyakarta, 2008.

Munir Fuady, Arbitrase Nasional: Alternative Penyelesaian Sengketa Bisnis, PT. Citra Aditya Bakti, Bandung, 2005. 
M. Yahya Harahap, Hukum Acara Perdata: tentang Gugatan, Persidangan, Penyitaan, Pembuktian dan Pututsan Pengadilan, Sinar Grafika, Jakarta, 2008.

Rahmadi Usman, Pilihan Penyelesaian Sengketa di Luar Pengadilan, PT Aditya Bakti, Bandung, 2003.

Rony Hanitijo soemitro, Metodelogi Penelitian Hukum dan Judimentri Ghalia Indonesia, Jakarta, 2000.

Rosyadi Rahmat dan Ngatino, Arbitrase dalam Hukum Islam dan Hukum Positif, PT. Citra Adiya Bakti, Bandung.

R. Tresna, Komentar HIR, Paradaya Paramita, Jakarta, 2005.

Subekti \& Tjitrosudibio, Kitab Undang-undang Hukum Perdata, Pradnya Paramita, Jakarta, 1985.

Tim Penyusun Kamus Pusat Pembinaan dan Pengembangan Bahasa, Kamus Besar Bahasa Indonesia, Balai Pustaka, Jakarta, 2000. 